\section{New private monopoly}

The British Government is turning its public

\section{telephone monopoly into a private ogre.}

THE British Government has landed itself in a serious conflict of interest. For more than two years, the government has been fighting through the British Parliament a bill to sell off British Telecom, the public monopoly that now provides telephone services in Britain. The government's motives are mostly laudable. It reckons that a telephone service which is a public company mostly owned by private individuals would be bound to conduct its affairs efficiently, returning a good profit in the ordinary way to its shareholders. That is true. So is the belief that the general public interest will be served by circumscribing the long-standing and much-used right of the public monopoly to be the sole supplier of the terminal equipment for all rented telephone lines. Some moves have already been made in that direction, and more are promised. But the British Government is also anxious that the sale of shares in British Telecom, due to take place within a year, should be a success in the commercial sense. The Chancellor of the Exchequer is counting on the proceeds to help reduce the government's need to borrow money from the financial markets in the years ahead, perhaps to the tune of $£ 4,000$ million. The trouble is that the last objective, prudent though it is, sharply conflicts with the objective that the market for the supply of telecommunications services should be genuinely competitive.

The strains are already shockingly apparent. For the past two years, British Telecom has been working a transitional arrangement for administering the approval of terminal equipment other than its own that may be connected to the public network. Technically, suppliers of alternative equipment have been required to submit items of equipment for approval to the Department of Trade and Industry, the government department in charge of telecommunications, which has then taken technical advice from none other than British Telecom, the organization most directly damaged by alternative sources of supply. Is it any wonder that approvals for alternative pieces of terminal equipment have been slow to trickle through? Or that alternative terminal equipment for which approval was withheld should have turned up among the items offered for sale by newly go-go British Telecom? (One such item is British Telecom's "Easa-Phone", essentially a National Panasonic product for whose independent sale a private company failed to get permission more than a year ago.)

Now the regime has changed, in that the British Standards Institution has published a complicated set of standard specifications for terminal equipment, and the business of licensing has been hived off to a nominally independent board, while under the new legislation there will be a new kind of regulatory body (called "'Oftel") to supervise the public monopoly when it goes private. The obvious snag is that Oftel's powers to control British Telecom when it has become a private company and a majority of its shares sold to private persons will be puny in comparison with those thought necessary elsewhere, in the United States for example. Thus while British Telecom is exhorted by its draft operating licence not to use the revenues from one service to subsidize another, innocence or guilt in this respect will be harder to establish when British Telecom is a private entity. No wonder that even Lord Weinstock, chairman of the General Electric Company (not to be mistaken for GE of the United States) and until recently the British Government's favourite industrialist, has been saying that the new legislation is simply a way of replacing a public by a private monopoly.

The government's dilemma is that it will not get the whole of its $£ 4,000$ million for the sale of shares if it allows British Telecom to be exposed to the full force of commercial competition for terminal equipment - not just handset and answering machines, but branch exchanges, computer equipment and the like. The calculation is probably correct but is also shortsighted. In the last complete financial year (to March 1983) the telephone system had revenues of $\mathbf{f 6 , 4 1 4}$, out of which it financed two-thirds of its capital development and yet managed to turn in a profit of nearly $£ 1,000$ million. (In the year just ended, the profits will be less because the nascent company is taking every chance to write off capital assets in advance of going public.) The business about to be sold to the public, in other words, is immensely profitable in commercial terms, charging so much for its services that it can make a handsome profit and at the same time provide the resources that will earn still larger profits in the future. It is in retrospect ironical that this practice has been forced on British Telecom by the British Government's past insistence that the telephone services should not add to its borrowing requirement, but as a consequence the shares soon to be sold will be among the best bargains the stock exchanges have seen for many years, making gentle nonsense of the government's promise that Oftel will not allow charges to increase as quickly as inflation for the next five years. But if, as seems possible, as much as a third of British Telecom's revenue may represent money that could be raised in other ways (by borrowing or raising further equity), it cannot be sensible that the Chancellor of the Exchequer should institutionalize a monopoly on such a scale for the sake of being able to sell a half-share in it for $£ 4,000$ million.

\section{Bad news for Unesco}

\section{The British shot across Unesco's bows is more}

\section{direct than the earlier US threat to withdraw.}

MR Timothy Raison, Minister of State at the British Overseas Development Administration, writes a better letter than $\mathrm{Mr}$ George Shultz, US Secretary of State. That is one conclusion to be drawn from a comparison of the letters the two politicians have been sending to Mr Amadou-Mahtar M'Bow, the director general of the United Nations Educational, Scientific and Cultural Organization (Unesco). Mr Shultz's letter last December announcing the still-intended withdrawal of the United States, went out of its way to say that the United States had "no complaint" about the director-general's administration of Unesco - and in the process made the proposed withdrawal less easily intelligible, and cast down the spirits of those working for the organization, many of whom consider that their employer is in a muddle, intellectual and administrative. Mr Raison's letter, earlier this month, should help the people in Paris know more clearly where they stand.

The British Government says that it welcomes the enlargement of Unesco's membership and the consequently increased attention being paid to the needs of developing countries, but that it has "felt unease" about the political aspects of certain programmes and that "above all" it fears that Unesco's programmes do not provide value for money. The letter goes on to say that the British Government will decide before the year is out whether to withdraw, looking for "significant indications of change" before then. The letter is accompanied by a list of what the British Government thinks should be done both to concentrate Unesco's programme on what it does well - or passably well - and to spend its resources more fruitfully.

Style apart, neither letter will be ignored. Unesco's willingness to open its books to the visiting audit from the United States (now in Paris) is one sign of that. The British letter, by being more specific, may be resented for appearing prescriptive but the points it makes are too cogent to be shuffled off, but are in any case backed up by the threat of a withdrawal. What neither letter says, however, is how Mr M'Bow should set about rescuing the agency of which he is the head from eventual collapse. Unesco is a potentially valuable organization, not merely because of the kinds of things is might do but because there are political circumstances (in India, or Yugoslavia, for example) where Unesco aid is more acceptable than bilateral aid. It is run down because it has been badly administered, because it pretends to be an expert body when it is not and, strangely, because it is desperately short of good ideas. If Mr M'Bow wants to save Unesco (or merely his present job), he should bend his energy to creating an imaginative role for an organization that has become dull. Or he should quit. 